This is the accepted typescript of an paper accepted (in 2017) for publication in Legal Studies.

Legal Studies is available online at https://www.cambridge.org/core/journals/legal-studies

This copy was deposited in Enlighten before the final version of the article was published; it will appear in due course. This copy may be used only for private research and study and not distributed further.

\title{
Criminal Law in the Shadows: Creating Offences in Delegated Legislation
}

\section{James Chalmers and Fiona Leverick}

\section{University of Glasgow*}

\section{ABSTRACT}

Substantial numbers of criminal offences are created in the UK in delegated legislation, often carrying heavy maximum penalties. The majority are created in statutory instruments passed under negative resolution procedure, which offers very limited opportunity for scrutiny and does not involve a parliamentary vote. This phenomenon has slipped under the radar of orthodox criminal law scholarship, where debate has focused primarily on the criteria that should be used to determine the content of the criminal law and on the principles to which such offences should conform, rather than on the process of creating criminal offences. Creating offences in delegated legislation raises questions of democratic legitimacy and has resulted in criminal offences being created which do not conform to basic principles of fair notice and proportionality of penalty. To address this, we propose that parliamentary approval should be required for all serious offences. It would be impractical to do this for all criminal offences, and direct participation in the legislative process via consultation can act as an alternative (or additional) legitimating principle. This does, however, require that the consultation process complies with certain basic minimum requirements, and we explain how these requirements might appropriately be framed.

\footnotetext{
${ }^{*}$ The research on which this paper is based was funded by the Leverhulme Trust. The authors would like to thank Lindsay Farmer, Tom Mullen and Findlay Stark and the anonymous reviewers for their helpful comments on earlier versions and Alasdair Shaw and Peter Lewin for their research assistance at various stages of the project.
} 
This is the accepted typescript of an paper accepted (in 2017) for publication in Legal Studies. Legal Studies is available online at https://www.cambridge.org/core/journals/legal-studies

This copy was deposited in Enlighten before the final version of the article was published; it will appear in due course. This copy may be used only for private research and study and not distributed further.

\section{INTRODUCTION}

The Law Commission has described the decision about whether or not to create a criminal offence as 'a law-creating step of great (arguably, of something approaching constitutional) significance'. ${ }^{1}$ A substantial body of work considers the appropriate content of the criminal law and attempts to find a set of workable criteria that can be used to make criminalisation decisions. ${ }^{2}$ What has received less attention is the process by which criminal offences are created. Where this is mentioned at all, it tends to be assumed that proposals to create offences are voted on by Parliament before they become law. ${ }^{3}$ Indeed, it has even been suggested that the decision to criminalise is so serious that it should require a Parliamentary 'supermajority'. ${ }^{4}$

In this paper, we demonstrate that in reality the majority of criminal offences are created not in statutes, but in secondary legislation that is often not subject to a parliamentary vote at all. ${ }^{5}$ What is more, the majority of offences created in this way carry heavy maximum penalties. ${ }^{6}$ The mass creation of criminal offences in secondary legislation presents at the very least a challenge to the democratic legitimacy of the criminal law and, due to the limited scrutiny it receives in comparison to primary legislation, raises concerns about the extent to which it conforms to important principles, such as accessibility and fair notice, and proportionality of penalty. This also presents a challenge to the orthodox position in criminal law scholarship, which (as proposals for 'supermajorities' indicate) frequently treats criminalisation as a solemn decision of the legislature when, in reality, it is a rather

\footnotetext{
${ }^{1}$ Law Commission Criminal Liability in Regulatory Contexts (Consultation Paper No 195, 2010) at para 1.49.

${ }^{2}$ See e.g. D Husak Overcriminalization: The Limits of the Criminal Law (Oxford: Oxford University Press, 2008); RA Duff et al (eds) The Boundaries of the Criminal Law (Oxford: Oxford University Press, 2010); AP Simester and A von Hirsch Crimes, Harms, and Wrongs: On the Principles of Criminalisation (Oxford: Hart, 2014).

${ }^{3}$ See e.g. P Westen 'Two rules of legality in criminal law' (2007) 26 Law and Philosophy 289 at 289; D Ormerod and K Laird Smith and Hogan's Criminal Law (Oxford: Oxford University Press, 14th edn, 2015) 3.

${ }^{4} \mathrm{P}$ Tomlin 'Extending the golden thread? Criminalisation and the presumption of innocence' (2013) 22 Journal of Political Philosophy 44 at 65; DA Dripps 'The liberal critique of the harm principle' (1998) 17 Criminal Justice Ethics 3 at 12 .

${ }^{5}$ See table 1 below.

${ }^{6}$ As table 2 below shows, many are imprisonable.
} 
This is the accepted typescript of an paper accepted (in 2017) for publication in Legal Studies.

Legal Studies is available online at https://www.cambridge.org/core/journals/legal-studies

This copy was deposited in Enlighten before the final version of the article was published; it will appear in due course. This copy may be used only for private research and study and not distributed further.

more routine, even administrative, action. In this paper, building on previous work tracking the creation of criminal offences by legislation, ${ }^{7}$ we assess the democratic legitimacy of criminalisation by means of delegated legislation. We argue that creating offences in delegated legislation is problematic in this respect and that parliamentary approval should be required for serious offences (with seriousness being defined by the maximum term of imprisonment that can be imposed). It would, for reasons of available parliamentary time, be impractical to do this for all criminal offences, and we argue that that direct participation in the legislative process via consultation can act as an alternative (or additional) legitimating principle. This does, however, require that the consultation process complies with certain basic minimum requirements. The Administrative Procedure Act 1946, which regulates the making of secondary legislation in the US, would be a good starting point for developing these.

\section{THE CREATION OF CRIMINAL OFFENCES IN SECONDARY LEGISLATION}

\section{(a) The criminal offences research}

The findings presented in this paper stem from a research project tracking the creation of criminal offences in selected periods from the 1950s until the present day. The project was motivated by the political debate in the UK over the (allegedly) excessive creation of offences - the Labour government elected in 1997 was, notably, accused of creating them at a rate of around one per day, ${ }^{8}$ and the Coalition government created a "gateway" mechanism for the specific purpose of reviewing all proposals for the creation of criminal offences. ${ }^{9}$ Our research examined four sample time periods. In the first three, we looked at the first twelve months following the election of a new government

\footnotetext{
${ }^{7}$ See e.g. J Chalmers and F Leverick 'Tracking the creation of criminal offences' [2013] Crim LR 543; J Chalmers, F Leverick and A Shaw 'Is formal criminalisation really on the rise? Evidence from the 1950s' [2015] Crim LR 177.

${ }^{8} \mathrm{~N}$ Morris 'Blair's 'frenzied law making': a new offence for every day spent in office', The Independent, 16 August 2006.

${ }^{9}$ For discussion, see Chalmers and Leverick, above $\mathrm{n} 7$.
} 
This is the accepted typescript of an paper accepted (in 2017) for publication in Legal Studies.

Legal Studies is available online at https://www.cambridge.org/core/journals/legal-studies

This copy was deposited in Enlighten before the final version of the article was published; it will appear in due course. This copy may be used only for private research and study and not distributed further.

and in the fourth at a single calendar year. ${ }^{10}$ We reviewed all Acts of Parliament that received Royal

Assent, and all statutory instruments that were made, in order to identify every criminal offence created therein. The exercise was not straightforward - especially given that criminal offences are mostly found in legislation that is not obviously identified as criminal ${ }^{11}-$ and we have discussed elsewhere the methodological challenges that we encountered. ${ }^{12}$ These aside, what this exercise demonstrated was two-fold. First, the figures quoted in political debates were, if anything, significant under-estimates. Secondly, the creation of large numbers of criminal offences is not a new phenomenon. Successive governments since the 1950s have created criminal offences at a far higher rate than had been previously assumed. So, for example, 1235 criminal offences applicable to England and Wales were created by the New Labour government in the first 12 months following their election. The number created by the coalition government in their 12 months in office was lower, at 634 , but this still far exceeded the 'one offence for every day in government' claim. ${ }^{13}$

\section{(b) How were all these criminal offences created?}

One might wonder how Parliament coped with creating offences in such large numbers. The simple answer is that it did not, as the vast majority were created in secondary legislation. This is clear from table 1 , which displays the mode of creation of the criminal offences in each of our sample periods.

\footnotetext{
${ }^{10}$ The initial periods assessed were the 12 months following the election of the 'New Labour' government in 1997 and the Coalition government in 2010. A third analysis following the 1951 election of a Conservative government provided a historical baseline. The analysis concluded with the calendar year 2014 in order to provide a more recent picture than that available from the initial samples.

${ }^{11}$ PR Ferguson 'Criminal law and criminal justice: an exercise in ad hocery', in EE Sutherland et al (eds) Law Making and the Scottish Parliament: The Early Years (Edinburgh: Edinburgh University Press, 2011) 208 at 218.

${ }^{12}$ Chalmers and Leverick, above $n$ 7, at 548-550; Chalmers et al, above $n 7$, at 179-180.

${ }^{13}$ Chalmers and Leverick, above $\mathrm{n} 7$, at 551 . We make no claim here about whether the number of offences created by legislation (whether primary or secondary) represents overcriminalisation. It is doubtful that such a conclusion can be reached by a numerical analysis alone, and the extensive use of criminal law in this way must be understood in the broader context of the regulatory role of governments: see J Horder 'Bureaucratic criminal law: too much of a good thing?', in RA Duff et al (eds) Criminalization: The Political Morality of the Criminal Law (Oxford: Oxford University Press, 2014) 101.
} 
This is the accepted typescript of an paper accepted (in 2017) for publication in Legal Studies.

Legal Studies is available online at https://www.cambridge.org/core/journals/legal-studies

This copy was deposited in Enlighten before the final version of the article was published; it will appear in due course. This copy may be used only for private research and study and not distributed further.

Table 1: Mode of creation of criminal offences

\begin{tabular}{|l|c|c|c|}
\hline & Statute & Statutory instrument & Total \\
\hline $1951-52$ & $159(18 \%)$ & $704(82 \%)$ & 863 \\
\hline $1997-98$ & $18(1 \%)$ & $1377(99 \%)$ & 1395 \\
\hline $2010-11$ & $247(14 \%)$ & $1513(86 \%)$ & 1760 \\
\hline 2014 & $171(8 \%)$ & $1935(92 \%)$ & 2106 \\
\hline
\end{tabular}

As table 1 indicates, in every single 12 month period we examined, ${ }^{14}$ the vast majority of criminal offences were created in statutory instruments. This was especially notable in 1997-98 when, of the 1395 criminal offences that were created, ${ }^{15} 1377$ (99 per cent) were in statutory instruments, but the general pattern is replicated across each one of the sample time periods.

It might be assumed that the use of statutory instruments to create criminal offences would be limited to those attracting relatively minor penalties, but this is not the case. Table 2 displays the maximum penalty on conviction for the offences created. In every time period we examined, a sizeable number of offences created by statutory instrument were potentially punishable by imprisonment. The deprivation of liberty is obviously a severe sanction but almost as significant is that in each period, a sizeable number of offences created by statutory instrument were punishable by an unlimited fine.

Table 2: Maximum penalty on conviction for offences created by statutory instrument

\footnotetext{
${ }^{14}$ For evidence of the use of secondary legislation to create criminal offences prior to the 1950s, see Horder, above $\mathrm{n} 13$, at 108 .

${ }^{15}$ The figure here differs to that of 1235 mentioned above because it includes not only offences applicable to England and Wales but also those applicable to other parts of the UK.
} 
This is the accepted typescript of an paper accepted (in 2017) for publication in Legal Studies.

Legal Studies is available online at https://www.cambridge.org/core/journals/legal-studies

This copy was deposited in Enlighten before the final version of the article was published; it will appear in due course. This copy may be used only for private research and study and not distributed further.

\begin{tabular}{|l|c|c|c|}
\hline & Fine (limited) & Fine (unlimited) & Imprisonment \\
\hline $1951-52$ & $136(19 \%)$ & $36(5 \%)$ & $532(76 \%)$ \\
\hline $1997-98$ & $281(20 \%)$ & $200(15 \%)$ & $896(65 \%)$ \\
\hline $2010-11$ & $536(35 \%)$ & $110(7 \%)$ & $867(57 \%)$ \\
\hline 2014 & $1276(66 \%)$ & $21(1 \%)$ & $638(33 \%)$ \\
\hline
\end{tabular}

Further evidence of the seriousness of these offences is shown in table $3,{ }^{17}$ which focuses solely on the offences created by statutory instrument where the maximum penalty available upon conviction was imprisonment. As table 3 shows, in every sample period a considerable number of offences with maximum penalties of two or more years' imprisonment were created in statutory instruments. One period that stands out in this respect is 1951-52 where 483 offences with a maximum penalty of two years' imprisonment were created by statutory instrument - 91 per cent of all imprisonable offences created in this way - although this can in part be attributed to a particularly over-broad method of drafting used at the time. ${ }^{18}$ Even in the more recent sample periods, though, the offences created by statutory instrument were highly punitive. In 2010-11, 133 offences were created by statutory instrument that had a maximum penalty of five years' imprisonment. ${ }^{19}$ In the 2014 sample there were 390 criminal offences created by statutory instrument with a maximum penalty of two years' imprisonment and 57 with a maximum penalty greater than this (two at five years, 50 at seven years and five at ten years).

\footnotetext{
${ }^{16}$ These figures include fines limited by reference to the standard scale, prescribed sum, and nominal limits. For the standard scale and prescribed sum, see the Interpretation Act 1978 Sch 1 and references therein.

17 Some of the percentage totals exceed 100 due to rounding. There were no maximum penalties of more than one year but less than two years' imprisonment in the relevant years.

18 Under the Defence (General) Regulations 1939, whereby contravention of or non-compliance with any provision was deemed an offence with a maximum penalty of two years' imprisonment: see Chalmers et al, above $\mathrm{n}$, at 189-190.

${ }^{19}$ Including 130 created by a single instrument, the Water Environment (Controlled Activities) (Scotland) Regulations 2011 (SSI 2011/209).
} 
This is the accepted typescript of an paper accepted (in 2017) for publication in Legal Studies.

Legal Studies is available online at https://www.cambridge.org/core/journals/legal-studies

This copy was deposited in Enlighten before the final version of the article was published; it will appear in due course. This copy may be used only for private research and study and not distributed further.

Table 3: Maximum penalty for imprisonable offences created by statutory instrument

\begin{tabular}{|l|c|c|c|}
\hline & 1 month to 1 year & 2 years & More than 2 years \\
\hline $1951-52$ & $49(9 \%)$ & $483(91 \%)$ & None \\
\hline $1997-98$ & $210(24 \%)$ & $664(74 \%)$ & $22(2 \%)$ \\
\hline $2010-11$ & $379(45 \%)$ & $355(41 \%)$ & $133(15 \%)$ \\
\hline 2014 & $191(30 \%)$ & $390(61 \%)$ & $57(9 \%)$ \\
\hline
\end{tabular}

The fact that so many criminal offences were created by statutory instrument in the UK and that so many were accompanied by high maximum penalties was an unexpected finding of our research. In Criminal Liability in Regulatory Contexts, the Law Commission expressed concern that it is 'far too easy' $^{\prime 20}$ to create criminal offences via secondary legislation, but cited only one example of an imprisonable offence created in this way. ${ }^{21}$ Our research demonstrates that delegated legislation is, in fact, the method by which the vast majority of criminal offences are created in the UK. Aside from the Law Commission's report, however, this issue sits in the shadows, barely noticed or subjected to critical scrutiny. ${ }^{22}$

One reason why this issue has received so little attention may be that most offences created by statutory instrument are not offences of general application. Rather, they are special capacity offences $^{23}$ - offences directed towards those operating in a specific role. So, for example, in the

\footnotetext{
${ }^{20}$ Law Commission, above $\mathrm{n} 1$, at para 1.49.

${ }^{21}$ Law Commission, above $\mathrm{n} 1$, at $\mathrm{n} 105$.

${ }^{22}$ For a rare example of discussion in the UK context, see J Horder Ashworth's Principles of Criminal Law (Oxford: Oxford University Press, 8th edn, 2016) at 60-64.

${ }^{23}$ Such offences are sometimes termed 'regulatory' but we avoid that term as there is disagreement over its meaning: see G Smith et al, 'Regulation and criminal justice: exploring the connections and disconnections', in $\mathrm{H}$ Quirk et al (eds) Regulation and Criminal Justice: Innovations in Policy and Research (Cambridge: Cambridge University Press, 2010) at 2-4.
} 
This is the accepted typescript of an paper accepted (in 2017) for publication in Legal Studies.

Legal Studies is available online at https://www.cambridge.org/core/journals/legal-studies

This copy was deposited in Enlighten before the final version of the article was published; it will appear in due course. This copy may be used only for private research and study and not distributed further.

2010-11 sample, only 11 per cent of the offences created in that 12 month period were targeted at the public at large. The remainder were either explicitly or implicitly targeted at persons engaging in a specialist activity, most commonly those operating in the course of a particular business. ${ }^{24}$ The figures were similar for the other time periods. ${ }^{25}$

This does not mean that these offences should escape scrutiny. The possible consequences for those convicted - even if they are operating in the course of a business or other specialist activity - are still very serious. Conviction carries with it considerable stigma and has collateral consequences beyond any sentence imposed. ${ }^{26}$ It might be assumed that for many special capacity offences, it is a legal entity rather than an individual that would be the target of any prosecution. Our own data suggests, however, that many of these offences clearly envisage individual liability, being targeted at, for example, the 'master of a ship' or other type of role. ${ }^{27}$ Even where liability is imposed on a legal entity, the collateral consequences of conviction can still be severe in terms of reputation and resulting loss of business. ${ }^{28}$ It should also be noted that the majority of businesses targeted by the offences are not large ones who can afford in-house legal teams or specialist legal advice. Many will be small family run businesses or sole traders (liable, in any event, to prosecution as individuals). ${ }^{29}$

Another reason why the offences created in secondary legislation have escaped scrutiny may be that they are rarely prosecuted, as regulators use the threat of prosecution as a means to secure

\footnotetext{
${ }^{24}$ See Chalmers and Leverick, above $\mathrm{n} 7$, at 557.

${ }^{25}$ See ibid, at 557; Chalmers et al, above $n$ 7, at 186-189.

${ }^{26}$ See e.g. S Ispa-Landa and CE Loeffler 'Indefinite punishment and the criminal record: stigma reports among expungement-seekers in Illinois' (2016) 54 Criminology 387.

27 See the table in Chalmers et al, above $n$ 7, at 186.

${ }^{28}$ See e.g. L Friedman 'In defense of corporate criminal liability' (2000) 23 Harvard J of L and Public Policy 833.

${ }^{29}$ The Law Commission quotes Department for Business, Enterprise and Regulatory Reform figures that estimate that $96 \%$ of the UK's 4.7 million private businesses have fewer than 10 employees (Law Commission, above $\mathrm{n}$, at para 7.6).
} 
This is the accepted typescript of an paper accepted (in 2017) for publication in Legal Studies.

Legal Studies is available online at https://www.cambridge.org/core/journals/legal-studies

This copy was deposited in Enlighten before the final version of the article was published; it will appear in due course. This copy may be used only for private research and study and not distributed further.

compliance, prosecuting only as a last resort. ${ }^{30}$ Even if prosecutions are rare, however, the creation of these offences still imposes compliance costs, whether financial or in the form of restrictions on freedom of action. Nor should the significance of an offence be dismissed simply because it is rarely prosecuted; even if prosecutions are rare there is a danger that they are arbitrary, causing substantial injustice to those who are prosecuted and convicted. ${ }^{31}$

The creation of criminal offences in statutory instruments raises two inter-related questions: principled questions of democratic legitimacy and practical questions of quality, given the limited scrutiny secondary legislation receives. In order to address these questions, however, it is necessary first to consider the process by which statutory instruments are made.

\section{HOW ARE STATUTORY INSTRUMENTS MADE?}

The process by which primary legislation is made is relatively well understood. In the UK Parliament, Bills are given a first and second reading in either the Commons or the Lords before passing to the Committee stage where they are scrutinised line by line by the appropriate Public Bill Committee (or Committees) which produces a comprehensive report. Amendments may be tabled before the final Bill is voted on. If the Bill started in the Commons, the process is then repeated in the Lords and vice versa. In the Scottish Parliament, the process is similar but in the absence of a second chamber Committees play a more extensive role, normally scrutinising the general principles (at stage 1) and then the detail of the draft Bill (at stage 2) before the Bill is voted on by Parliament. In both Parliaments there is normally plenty of opportunity for detailed scrutiny of the legislation concerned. ${ }^{32}$

\footnotetext{
${ }^{30} \mathrm{~K}$ Hawkins Law as Last Resort: Prosecution Decision-Making in a Regulatory Agency (Oxford: Oxford University Press, 2002).

31 J Black 'Talking about regulation' [1998] PL 77 at 93.

32 For an overview, see M Zander The Law-Making Process (Cambridge: Cambridge University Press, 7th edn, 2015) ch 2.
} 
This is the accepted typescript of an paper accepted (in 2017) for publication in Legal Studies. Legal Studies is available online at https://www.cambridge.org/core/journals/legal-studies This copy was deposited in Enlighten before the final version of the article was published; it will appear in due course. This copy may be used only for private research and study and not distributed further.

It is the opportunity for detailed scrutiny that is vastly reduced when law is made by secondary legislation. As Page observes, '[t]he whole point of delegated legislation is that Parliament does not have to look at it closely'. ${ }^{33}$ There are a number of different types of secondary legislation but our focus here is on statutory instruments (SIs). $\mathrm{An} \mathrm{SI}^{34}$ can only be made if the power to make it is provided for in a statute (referred to here as an 'enabling' Act). The enabling Act sets out the scope of that power (typically a power given to a government minister to make regulations for a specific purpose) and specifies the procedure that must be used to make the regulations concerned.

There are two main procedures under which SIs can be made: negative resolution procedure (NRP) and affirmative resolution procedure (ARP). ${ }^{35} \mathrm{NRP}$ is more common - in the context of the UK Parliament it has been estimated that it is used for around 1100 Sls per year. ${ }^{36} \mathrm{ARP}$ is reserved for 'the most important delegations of power ${ }^{\prime 37}$ and is used in Westminster for around 200 instruments per year. ${ }^{38}$ In the context of the Scottish Parliament, there is some evidence that ARP is used to make a higher proportion of SSIs than it is to make SIs in Westminster, but NRP is still the most commonly used procedure..$^{39}$

\footnotetext{
${ }^{33}$ EC Page Governing by Numbers (Oxford: Hart, 2001) at 157.

${ }^{34}$ Unless specified otherwise, the term SI will be used here to incorporate SIs and SSIs (Scottish Statutory Instruments).

${ }^{35} \mathrm{R}$ Kelly House of Commons Background Paper: Statutory Instruments (London: House of Commons, SN/PC/6509, 2012), at 5. Almost all of the SIs in our sample were made under either NRP or ARP - see section 4 (b)(i) below. Statutory instruments can be made under procedures which are different from the general ones described here: see ibid at 11-14.

${ }^{36}$ House of Lords Briefing Looking at the Small Print: Delegated Legislation (London: House of Lords, 2009) at 2.

37 lbid.

${ }^{38} \mathrm{Ibid}$.

${ }^{39}$ In the Parliamentary session 2014-15, NRP was used to make 168 SSIs and ARP to make 97 SSIs: Delegated Powers and Law Reform Committee The Work of the Delegated Powers and Law Reform Committee in 2014-15 (Edinburgh: Scottish Parliament, 2015) at para 29.
} 
This is the accepted typescript of an paper accepted (in 2017) for publication in Legal Studies.

Legal Studies is available online at https://www.cambridge.org/core/journals/legal-studies

This copy was deposited in Enlighten before the final version of the article was published; it will appear in due course. This copy may be used only for private research and study and not distributed further.

Under NRP, no parliamentary vote is required for the SI to become law. The SI is made by the government department concerned and laid before Parliament. ${ }^{40}$ Unless there is a motion to annul (known as a prayer) within 40 days it will be passed. ${ }^{41} \mathrm{~A}$ similar procedure operates in the Scottish Parliament. $^{42}$

Once an SI has been laid, it is considered by two Committees, both of which meet weekly in order to ensure that scrutiny takes place within the 40 days praying time. ${ }^{43}$ The Joint Committee on Statutory Instruments (JCSI) ${ }^{44}$ examines whether the $\mathrm{SI}$ has been made in accordance with the powers set out in the enabling Act. ${ }^{45}$ It can also draw attention to an SI on any other grounds that do not impinge on the merits or the policy behind it. Such grounds include that it imposes a tax; that it is made in pursuance of any enactment containing specific provisions excluding it from challenge in the courts; or that it appears to have retrospective effect. ${ }^{46}$ As of the $2014-15$ parliamentary session, the JCSI has also been empowered to report an SI specifically on the ground that it has supporting material that is inadequate to explain the policy intention or that it has been subject to an inadequate consultation process. ${ }^{47}$ In Scotland technical scrutiny is undertaken by the Delegated Powers and Law Reform Committee (DPLRC) ${ }^{48}$ which can draw the attention of the Scottish Parliament to an SSI

\footnotetext{
${ }^{40}$ Kelly, above $\mathrm{n} 35$, at 5.

${ }^{41}$ Statutory Instruments Act 1946 s 5(1). Very occasionally the instrument is laid in draft and cannot be made if the draft is disapproved within 40 days. Sls subject to this procedure are 'few and far between' (ibid, at 5) and there were none in our sample.

${ }^{42}$ See the Interpretation and Legislative Reform (Scotland) Act 2010. NRP is set out in s 28 and s 28(3) provides for the 40 day period.

${ }^{43}$ Secondary Legislation Scrutiny Committee terms of reference $1(a)$.

${ }^{44} \mathrm{Or}$, for those involving only financial matters and therefore only the House of Commons, the Select Committee on Statutory Instruments.

45 Kelly, above $\mathrm{n} 35$, at 9.

${ }^{46}$ House of Commons Standing Order No.151 (and these are mirrored in House of Lords Standing Order No.74).

${ }^{47}$ House of Lords Guidance for Departments Submitting Statutory Instruments to the Secondary Legislation Scrutiny Committee (London: House of Lords, 2016) at 2.

${ }^{48}$ Previously known as the Subordinate Legislation Committee.
} 
This is the accepted typescript of an paper accepted (in 2017) for publication in Legal Studies.

Legal Studies is available online at https://www.cambridge.org/core/journals/legal-studies

This copy was deposited in Enlighten before the final version of the article was published; it will appear in due course. This copy may be used only for private research and study and not distributed further.

on grounds broadly similar to those of the JCSI, ${ }^{49}$ although it differs from the JCSI in that its business is conducted in public. ${ }^{50}$

The JCSI (or the Scottish DPLRC) cannot examine the merits of the SI, but some scrutiny is carried out in Westminster by the Secondary Legislation Scrutiny Committee (SLSC), ${ }^{51}$ which considers the 'policy implications' of SIs. It can draw the attention of MPs to an instrument on the basis that, inter alia, 'it is politically or legally important or gives rise to issues of public policy likely to be of interest to the House', 'it may inappropriately implement European Union legislation', or 'it may imperfectly achieve its policy objectives' ${ }^{.2}$ In Scotland there is no merits committee specifically charged with examining SSIs but scrutiny is undertaken by the standing committee under which the subject matter of the SSI falls. ${ }^{53}$

Although the fact of their existence may act as an indirect control on government power, ${ }^{54}$ none of the Committees discussed above have any direct powers. If they feel that an instrument is problematic, all that they can do is flag this up as a concern. It is then incumbent on an $\mathrm{MP}^{55}$ to put

\footnotetext{
${ }^{49}$ Standing Orders of the Scottish Parliament, Rule 10.3.1 (DPLRC). The power to draw attention on the basis that the supporting material does not adequately explain the policy intention or that inadequate consultation has taken place has not specifically been given to the DPLRC but it could report an instrument for these reasons under its general power to report an instrument on 'any other ground which does not impinge on its substance or on the policy behind it'.

${ }^{50}$ DPLRC, Remit and Responsibilities, 1(b), available at http://www.scottish.parliament.uk/parliamentarybusiness/CurrentCommittees/64221.aspx.

${ }^{51}$ Previously known as the Merits of Statutory Instruments Committee.

${ }^{52}$ Guidance for Departments, above $n$ 47, at 2.

${ }^{53}$ Standing Orders of the Scottish parliament, Rule 10.2.1 (DPLRC).

${ }^{54}$ JD Hayhurst and P Wallington 'The Parliamentary scrutiny of delegated legislation' [1988] PL 547 at 574.

${ }^{55}$ Or a member of the House of Lords or, in Scotland, an MSP.
} 
This is the accepted typescript of an paper accepted (in 2017) for publication in Legal Studies. Legal Studies is available online at https://www.cambridge.org/core/journals/legal-studies

This copy was deposited in Enlighten before the final version of the article was published; it will appear in due course. This copy may be used only for private research and study and not distributed further.

forward a motion to annul. ${ }^{56}$ Such motions are very rare ${ }^{57}$ and even where they do happen, it is often the case that no time for debate is made available. ${ }^{58}$ In the UK Parliament, the last time that a motion to annul was successful was in 2000 , when the House of Lords rejected the Greater London Authority Elections Rules. ${ }^{59}$ The House of Commons last annulled an SI in $1979 .{ }^{60}$

This has led many - including those who have served on the Committees as MPs ${ }^{61}$ or as Clerks ${ }^{62}-$ to criticise NRP as lacking any effective mechanism for scrutiny. ${ }^{63}$ The 40 day praying time has been said to be far too short, ${ }^{64}$ especially as no account is taken of any time during which Parliament is dissolved or prorogued, or during which both Houses are adjourned for more than four days ${ }^{65}$ This is particularly problematic as the instrument is not scrutinised by the relevant Committees until it has been laid before parliament, which means that it is very difficult for the Committees to produce reports in time for them to influence debate. ${ }^{66}$

\footnotetext{
56 There have been instances where, following a report, the Government has committed to amend an instrument at the next available opportunity. See, for example, the Animal Feed (England) Regulations 2010, which were reported by the JCSI for imposing requirements in relation to the labelling of animal feed but failing to identify the person whose responsibility it was to ensure that these requirements were complied with. The Food Standards Agency undertook to amend the SI at the next available opportunity: see R Fox and J Blackwell The Devil is in the Detail: Parliament and Delegated Legislation (London: Hansard Society, 2014) at 202. The Regulations were amended but not until three years later: see the Feed (Hygiene and Enforcement) and the Animal Feed (England) (Amendment) Regulations 2013.

57 In the context of the Scottish Parliament, there was only one motion to annul in the parliamentary session 2014-15 and it was withdrawn. This was despite 64 instruments being reported by the DPLRC during this period: see DPLRC, above $\mathrm{n} 39$, at paras 46 and 130. See similarly (writing about Westminster) Hansard Society Lifting the Lid on Delegated Legislation: Issues and Questions Paper (London: Hansard Society, 2013) at 3.

${ }^{58}$ AF Bennett 'Uses and abuses of delegated power' (1990) 11 Stat LR 23 at 26.

59 See Kelly, above n 35, at 7.

${ }^{60}$ The Paraffin (Maximum Retail Prices) (Revocation) Order 1979 (SI 1979/797). See ibid, at 7.

${ }^{61}$ A Beith 'Prayers unanswered: a jaundiced view of the Parliamentary scrutiny of statutory instruments' (1981) 34 Parliamentary Affairs 165; Bennett, above n 58.

62 P Tudor 'Secondary legislation: second class or crucial?' (2000) 21 Stat LR 149.

${ }^{63}$ See e.g. M Asimow 'Delegated legislation: United States and United Kingdom' (1983) 3 OJLS 253 at 266; G Ganz 'Delegated legislation: a necessary evil or a constitutional outrage?' in P Leyland and T Woods (eds) Administrative Law Facing the Future: Old Constraints and New Horizons (Oxford: Oxford University Press, 1997) 61 at 66-75.

${ }^{64}$ Asimow, above $n$ 63, at 266.

${ }^{65}$ Statutory Instruments Act 1946 s 7(1). The same is true of SSIs: see Interpretation and Legislative Reform (Scotland) Act 2010 s 28(3).

${ }^{66}$ Hayhurst and Wallington, above n 54, at 557.
} 
This is the accepted typescript of an paper accepted (in 2017) for publication in Legal Studies.

Legal Studies is available online at https://www.cambridge.org/core/journals/legal-studies

This copy was deposited in Enlighten before the final version of the article was published; it will appear in due course. This copy may be used only for private research and study and not distributed further.

ARP might be seen as an improvement on NRP in that it does at least require a positive parliamentary vote for the SI to become law. Under ARP, an instrument is either laid in draft and cannot be made unless the draft is approved by both Houses, or it is laid after making but cannot come into force unless it is approved. ${ }^{67}$ Instruments made under ARP are subject to the scrutiny of the JCSI and the SLSC in the same way as those made under NRP but in addition all SIs made under ARP are referred to a Delegated Legislation Committee (DLC), a committee that is set up specifically to debate the instrument in question. ${ }^{68} \mathrm{~A}$ DLC cannot, however, vote for or against the $\mathrm{SI}$ - at the conclusion of the debate it can report only that it has 'considered' the instrument - and debates cannot last for more than an hour and a half..$^{69}$ The SI then proceeds to a Parliamentary vote. Except in extremely rare instances where the enabling Act provides otherwise, ${ }^{70}$ an SI cannot be amended or adapted by either House - the instrument is either approved or it is not. ${ }^{71}$ ARP procedure in Scotland is similar. ${ }^{72}$

Aside from the (limited) examination of SIs that takes place once they have been made, there are two other points at which some independent control can be exerted. First, all proposals to delegate powers contained within primary legislation are examined by a House of Lords Select Committee, the Delegated Powers and Regulatory Reform Committee (DPRRC), which can report draft Bills if they contain inappropriate delegations of power or if they provide for inappropriate procedures to

\footnotetext{
${ }^{67}$ Kelly, above $\mathrm{n} 35$, at 5-7. Occasionally an instrument is laid after making and comes into force immediately but cannot remain in force unless approved within a certain period (usually 28 or 40 days). This was not the case for any of the SIs in our sample.

68 Ibid, at 10.

${ }^{69}$ Or two and a half hours if the instrument relates exclusively to Northern Ireland: see Kelly, above n 35 , at 10.

${ }^{70}$ See e.g. the Census Act 1920.

${ }^{71}$ Kelly, above $\mathrm{n} 35$, at 6.

72 Interpretation and Legislative Reform (Scotland) Act 2010, s 29. Instruments only require the approval of the Scottish Parliament as there is no second chamber. As in Westminster, amendment is not possible.
} 
This is the accepted typescript of an paper accepted (in 2017) for publication in Legal Studies.

Legal Studies is available online at https://www.cambridge.org/core/journals/legal-studies

This copy was deposited in Enlighten before the final version of the article was published; it will appear in due course. This copy may be used only for private research and study and not distributed further.

make delegated legislation (such as the use of NRP for a significant matter). ${ }^{73}$ The same function is

performed in Scotland by the DPLRC. ${ }^{74}$ Both Committees do pay particular attention to the power to create criminal offences ${ }^{75}$ and have, for example, acted to prevent the delegation of the power to create criminal offences with unlimited penalties ${ }^{76}$ Like the other Committees dealing with delegated legislation, however, they have no direct power and can only report matters of concern back to the government (in the hope that it will amend the Bill) or to MPs or MSPs. ${ }^{77}$

Secondly, there is some opportunity for judicial control over Sls once they have been made. An instrument can be declared ultra vires if it goes beyond the powers set out in the enabling Act, or on the basis of irrationality or incompatibility with the Human Rights Act, ${ }^{78}$ but successful challenges are rare.$^{79} \mathrm{An}$ instrument can also be declared invalid if it has not been made in accordance with the process set out in the enabling legislation, but again instances where instruments have been successfully challenged on this basis are rare $^{80}$ and procedural errors do not necessarily lead to the instrument being quashed. ${ }^{81}$

\section{DEMOCRATIC LEGITIMACY}

\footnotetext{
${ }^{73}$ http://www.parliament.uk/business/committees/committees-a-z/lords-select/delegated-powers-andregulatory-reform-committee/role/.

${ }^{74}$ Standing Orders of the Scottish Parliament, Rule 10.3.1.

${ }^{75}$ See e.g. Delegated Powers and Regulatory Reform Committee Guidance for Departments on the Role and Requirements of the Committee (London: House of Lords, 2014) at para 38.

${ }^{76}$ See e.g. Official Report, Delegated Powers and Law Reform Committee, 4 March 2014, col 1336 (in relation to the Tribunals (Scotland) Act 2014).

77 DPRRC, above $\mathrm{n} 75$, at para 26.

${ }^{78}$ P Craig Administrative Law (London: Sweet and Maxwell, 8th edn, 2016), at paras 15-025 to 15-033.

${ }^{79}$ See e.g. $R v$ Secretary of State for the Environment, Transport and the Regions, ex parte Spath Holme Ltd [2000] 1 All ER 884, where the court held that the Rent Acts (Maximum Fair Rent) Order 1999 was invalid because it went beyond the powers set out in the Landlord and Tenant Act 1985.

${ }^{80}$ See e.g. Agricultural, Horticultural and Forestry Industry Trading Board v Aylesbury Mushrooms Ltd [1972] 1 WLR 190 where the court held that the Industrial Training (Agricultural, Horticultural and Forestry Board) Order 1966 had no application to mushroom growers because the minister did not comply with his legal duty to consult them before the Order was made.

${ }^{81}$ See e.g. $R$ v Secretary of State for Social Services, ex parte Association of Metropolitan Authorities [1992] 25 HLR 131 at 139.
} 
This is the accepted typescript of an paper accepted (in 2017) for publication in Legal Studies. Legal Studies is available online at https://www.cambridge.org/core/journals/legal-studies

This copy was deposited in Enlighten before the final version of the article was published; it will appear in due course. This copy may be used only for private research and study and not distributed further.

\section{(a) What is required?}

The first question we consider is the degree to which the creation of criminal offences in secondary legislation is democratically legitimate. Legitimacy is a complex concept that has come to mean different things in different contexts ${ }^{82}$ (or even within the same context - legitimacy to a legal theory scholar is likely to mean something rather different to, say, a public law scholar). We are concerned here not with the legitimacy of a governing regime, ${ }^{83}$ but with the legitimacy of particular legal rules made under a regime that we assume, for the purposes of this paper, is a legitimate one. Our concern is specifically with democratic legitimacy, namely the requirement that a particular law must be tied in some way to the will of the people, democratically expressed. ${ }^{84}$ This is not by any means the only way in which one might approach the question of legitimacy. Democratic legitimacy is primarily a procedural concept - it is concerned with the input (direct or indirect) that citizens have into the law making process - but one might also conceive of legitimacy in other ways, such as the substantive justice of the measure concerned ${ }^{85}$ or its effectiveness in promoting welfare in practice.$^{86}$ We focus on democratic legitimacy here because it is particularly contentious when law is created in secondary legislation. ${ }^{87}$

\footnotetext{
${ }^{82}$ See e.g. D Beetham The Legitimation of Power (London: Palgrave Macmillan, 2nd edn, 2013) (political philosophy); M Weber The Theory of Social and Economic Organization (New York: The Free Press, 1964) (sociology); TR Tyler Why People Obey the Law (New Jersey: Princeton University Press, 2006) (criminology); M Suchman 'Managing legitimacy: strategic and institutional approaches' (1995) 20 Academy of Management Review 574 (management science).

83 On which see e.g. Beetham, above $n 82$.

${ }^{84}$ WJ Riker 'Democratic legitimacy and the reasoned will of the people', in DA Reidy and WJ Riker (eds), Coercion and the State (New York: Springer, 2008) 77 at 80; F Scharpf Governing in Europe: Effective and Democratic? (Oxford: Oxford University Press, 1999) at 6.

${ }^{85}$ For discussion of the relationship between procedural and substantive measures of legitimacy, see $\mathrm{W}$ Sadurski 'Law's legitimacy and “democracy plus"' (2006) 26 OJLS 377.

${ }^{86}$ See e.g. V Schmidt "Democracy and legitimacy in the European Union revisited: input, output and throughput" (2013) 61 Political Studies 2 at 7.

${ }^{87}$ Democratic legitimacy is also a particularly pertinent issue in the context of the European Union: see e.g. $D$ Beetham and C Lord Legitimacy and the European Union (Abingdon: Routledge, 1998); A Follesdal 'The legitimacy deficits of the European Union' (2006) 14 Journal of Political Philosophy 441.
} 
This is the accepted typescript of an paper accepted (in 2017) for publication in Legal Studies.

Legal Studies is available online at https://www.cambridge.org/core/journals/legal-studies

This copy was deposited in Enlighten before the final version of the article was published; it will appear in due course. This copy may be used only for private research and study and not distributed further.

The most obvious method of conferring democratic legitimacy is a parliamentary vote, whereby the legislation has secured the support of a majority of the people's elected representatives. ${ }^{88}$ This is not, however, the only way in which democratic legitimacy might be conferred. Indeed, a parliamentary vote might be seen as an imperfect route to democratic legitimacy of a particular legal measure as voters have no direct input into how their elected representative votes on a particular matter. ${ }^{89}$

An alternative to democratic legitimation by Parliament is legitimation by direct participation in the legislative process..$^{90}$ In practice, this is most likely to be achieved through consultation with relevant interest groups and others potentially affected by the legislation, as is required for delegated law making in the US. ${ }^{91} \mathrm{~A}$ participatory route to legitimacy has much to commend it. ${ }^{92}$ It provides an opportunity for those affected by the legislation to directly influence its content, something that can only be achieved indirectly where democratic legitimacy by parliamentary vote is concerned. ${ }^{93}$ It is, however, not without its dangers. A consultation might not reach all of those affected by the legislation. ${ }^{94}$ Even if it does, organisations or individuals may not have the time or necessary skills to respond and, even if they do, opportunities to exert influence are not equal and strong interest groups may exert disproportionate influence. ${ }^{95}$ Even a wide consultation does not necessarily equate to genuine participation, which requires something more than simply inviting comment, however

\footnotetext{
${ }^{88}$ Follesdal, above $n$ 87, at 448; H Pünder 'Democratic legitimation of delegated legislation: a comparative view on the American, British and German law' (2009) 58 ICLQ 353 at 356.

${ }^{89}$ A McHarg 'What is delegated legislation?' (2006) PL 539 at 556.

${ }^{90}$ Schmidt, above $\mathrm{n} 86$, at 6-7; C Lord and P Magnette 'E pluribus unum? Creative disagreement about legitimacy in the EU' (2004) 42 Journal of Common Market Studies 183 at 187.

${ }^{91}$ See text accompanying nn 193-202 below.

92 See e.g. J Elster Deliberative Democracy (New York: Cambridge University Press, 1997); A Gutmann and D Thompson, Why Deliberative Democracy? (New Jersey: Princeton University Press, 2004).

${ }^{93}$ Asimow, above $\mathrm{n} 63$, at 268.

94 Ibid, at 267.

95 Pünder, above n 88, at 375.
} 
This is the accepted typescript of an paper accepted (in 2017) for publication in Legal Studies.

Legal Studies is available online at https://www.cambridge.org/core/journals/legal-studies

This copy was deposited in Enlighten before the final version of the article was published; it will appear in due course. This copy may be used only for private research and study and not distributed further.

wide that invitation is extended. At the very least, it requires that the views of those affected by the law are accorded genuine weight and objections are properly considered and responded to.

\section{(b) The democratic legitimacy of criminal law made by statutory instruments}

How, then, do the criminal offence creating SIs fare on the two main measures of democratic legitimacy: parliamentary legitimacy and participatory legitimacy? To address this question, we look in more detail at the 2010-11 and 2014 samples in terms of three factors: the procedure by which the SIs were made (which would have been determined by the enabling legislation); whether the enabling legislation contained any other controls on the power of Ministers (specifically by creating a duty to consult or placing limits on the applicable penalties); and the extent to which consultation took place in practice.

\section{(i) The procedure used to make the instrument}

The criminal offences in the $2010-11$ sample were created by 87 different statutory instruments ${ }^{96}$ Of these, 19 were made under ARP and 68 under NRP. In the 2014 sample, the offences were created by 98 separate statutory instruments, ${ }^{97} 18$ of which were created using ARP and 80 using NRP. As we have already seen, there is no requirement for a parliamentary vote when an instrument is made under NRP and none of the instruments in our samples were the subject of a motion to annul, so the instruments made under NRP became law without any democratic legitimacy bestowed on them by Parliament other than indirectly via the enabling Act. While it might be argued that this is democratically legitimate, in the sense that Parliament has voted to allow law making to be delegated in this way, this is a very narrow concept of legitimacy which requires nothing more than

\footnotetext{
${ }^{96}$ Excluding three instruments of local application only.

${ }^{97}$ Excluding three instruments of local application only and nine instruments that were Orders in Council.
} 
This is the accepted typescript of an paper accepted (in 2017) for publication in Legal Studies.

Legal Studies is available online at https://www.cambridge.org/core/journals/legal-studies

This copy was deposited in Enlighten before the final version of the article was published; it will appear in due course. This copy may be used only for private research and study and not distributed further.

following a legally valid process and where the connection between the parliamentary vote and the resulting criminal measure becomes very remote.

(ii) The maximum penalty permitted

In terms of sanctions, both the DPRRC (in Westminster) and the DPLRC (in Scotland) have made it clear that it should be for Parliament to determine the maximum penalty for offences created by statutory instrument. ${ }^{98}$ For 64 of the 87 SIs in the 2010-11 sample, limits were placed in the relevant enabling legislation on the maximum penalties that could apply. For 23 of the Sls, however, there were no such limits. Even for the 67 SIs that were subject to limits, these were not especially restrictive, as table 4 shows.

Table 4: Maximum penalty specified in enabling legislation (number of SIs)

\begin{tabular}{|l|c|c|}
\hline & $2010-11$ & 2014 \\
\hline 5 years' imprisonment & 1 & 63 \\
\hline 2 years' imprisonment & 52 & 1 \\
\hline 51 weeks imprisonment & 2 & 5 \\
\hline 6 months imprisonment & 1 & 10 \\
\hline Fine only (unlimited) & 7 & 9 \\
\hline Fine only (limited) & 1 & 98 \\
\hline None & 23 & \\
\hline Total & & \\
\hline
\end{tabular}

98 DPRRC, above $n$ 75, at para 38; Official Report, Delegated Powers and Law Reform Committee, 4 March 2014, col 1336. 
This is the accepted typescript of an paper accepted (in 2017) for publication in Legal Studies.

Legal Studies is available online at https://www.cambridge.org/core/journals/legal-studies

This copy was deposited in Enlighten before the final version of the article was published; it will appear in due course. This copy may be used only for private research and study and not distributed further.

In the 2010-11 sample, in 52 instances, the enabling legislation still allowed for offences to be created with a maximum penalty of two years' imprisonment. ${ }^{99}$ In one instance, ${ }^{100}$ the enabling legislation allowed for offences to be created with a maximum penalty of up to five years' imprisonment. ${ }^{101}$ Where Parliament provided for maximum penalties, the resulting regulations always utilised the maximum penalty concerned. This meant that a significant number of offences were created under NRP with a maximum penalty of five years ${ }^{102}$ or two years' imprisonment. ${ }^{103}$

Matters improved somewhat in the 2014 sample, where limits were placed on maximum penalties in 88 of the 98 instruments. That still left 10 instruments that were not limited in this way and, as for the 2010-11 sample, the 'limits' in the remainder still allowed for the creation of offences in a sizeable number of cases with maximum sentences of two years' imprisonment or an unlimited fine.

\section{(iii) A statutory duty to consult?}

Of the 87 instruments in the $2010-11$ sample, 54 were subject to a legal duty to consult on the instrument while it was still in draft. Of the 98 instruments in the 2014 sample, the equivalent figure was 43. For many of the SIs concerned, the duty to consult arose because they related to food production and under EU law consultation is always required for regulations made in this area. ${ }^{104}$ In other instances the duty to consult stemmed from the enabling legislation, although the scope of the duty varied somewhat. So, for example, the Merchant Shipping Act 1995 provides only that, when

\footnotetext{
99 The majority of these were regulations implementing EU law made under the power in s 2 of the European Communities Act 1972. Sch 2 of the 1972 Act prohibits the creation of criminal offences with a maximum penalty of more than two years' imprisonment (see $s$ 1(1)(d)).

100 The Water Environment (Controlled Activities) (Scotland) Regulations 2011.

${ }^{101}$ Water Environment and Water Services (Scotland) Act 2003, Sch 2 para 20(2). It is unclear from the accompanying documentation to the Act why it was thought appropriate to allow for criminal offences to be created by secondary legislation with such a high maximum penalty.

102 The Water Environment (Controlled Activities) (Scotland) Regulations 2011 created 130 offences, all subject to a prescribed maximum penalty of five years' imprisonment.

${ }^{103}$ A total of 275 offences across 11 SIs.

104 EC Regulation 178/2002, article 9.
} 
This is the accepted typescript of an paper accepted (in 2017) for publication in Legal Studies.

Legal Studies is available online at https://www.cambridge.org/core/journals/legal-studies

This copy was deposited in Enlighten before the final version of the article was published; it will appear in due course. This copy may be used only for private research and study and not distributed further.

regulations are made under its auspices, ${ }^{105}$ it shall be the duty of the Secretary of State ... before he gives effect to the proposal, to consult such persons in the United Kingdom (if any) as he considers will be affected by the proposal' ${ }^{106}$ In comparison, the more specific duty contained in the Clean Air Act $1993^{107}$ provides that the Secretary of State must consult '(a) such persons appearing to him to represent manufacturers and users of motor vehicles; (b) such persons appearing to him to represent the producers and users of fuel for motor vehicles; and (c) such persons appearing to him to be conversant with problems of air pollution'. ${ }^{108}$ Sometimes the enabling legislation also set out the procedure that should be followed in the consultation. ${ }^{109}$

\section{(iv) Consultation in practice}

As noted above, the Government was subject to a legal duty to consult in relation to 54 of the SIs in the 2010-11 sample and 43 of the SIs in the 2014 sample. In all of these instances it is clear from the relevant Explanatory Memorandum to the SIs that consultation did take place prior to the instrument being made. ${ }^{110}$

That leaves 33 SIs in the 2010-11 sample and 55 in the 2014 sample that were not subject to a statutory duty to consult. Some of these (four in the 2010-11 sample and eleven in the 2014 sample) were made under ARP, and would have been the subject of a parliamentary vote, which perhaps makes this less of a pressing concern. For the remainder, the absence of a legal duty to consult did

\footnotetext{
105 In our sample, two SIs were made under the Merchant Shipping Act: the Merchant Shipping and Fishing Vessels (Health and Safety at Work) (Artificial Optical Radiation) Regulations 2010 and the Merchant Shipping and Fishing Vessels (Health and Safety at Work) (Asbestos) Regulations 2010.

${ }^{106}$ Merchant Shipping Act 1995 s 86(4).

107 Under which the Motor Fuel (Composition and Content) Regulations 2010 and the Merchant Shipping (Prevention of Air Pollution from Ships) (Amendment) Regulations 2010 were made.

${ }^{108}$ Clean Air Act 1993 s 30(2).

109 See e.g. Public Services Reform (Scotland) Act 2010 s 26 (the enabling Act for three sets of Regulations in our sample).

110 The standard pro forma for writing an Explanatory Memorandum for a statutory instrument includes a mandatory section on the outcome of any consultation that was undertaken. See Statutory Instrument Practice, Circular No.2 (10), 28 May 2010.
} 
This is the accepted typescript of an paper accepted (in 2017) for publication in Legal Studies.

Legal Studies is available online at https://www.cambridge.org/core/journals/legal-studies

This copy was deposited in Enlighten before the final version of the article was published; it will appear in due course. This copy may be used only for private research and study and not distributed further.

not necessarily mean that there was no consultation process in practice - in fact for a sizeable number of the SIs concerned (ten of the 2010-11 sample and 27 of the 2014 sample) there was. ${ }^{111}$

This still left a number of SIs across the two samples that were made under NRP and were not consulted on while in draft. Most were regulations giving effect to decisions of the UN Security Council. ${ }^{112}$ Aside from these, there were five instruments in the 2010-11 sample and three in the 2014 sample that were made under NRP and where no consultation on a draft order appears to have taken place. ${ }^{113}$ For one there was an earlier consultation around the general policy principles. ${ }^{114}$ For another the government made reference in its explanatory memorandum to the consultation that had taken place around the enabling Act. ${ }^{115}$ For another the government reported that it had discussed the need for the legislation in the course of regular meetings it held with industry representatives and stated that the group supported the need for the Order in question. ${ }^{116}$ For another the government reported that 'discussion' with representative stakeholder bodies had taken place. ${ }^{117}$

\footnotetext{
${ }^{111}$ See e.g. Explanatory Memorandum to the Ecodesign for Energy-Related Products Regulations 2010 at para 8; Explanatory Memorandum to the Electronic Money Regulations 2011 at para 8.

${ }^{112}$ See e.g. the Democratic People's Republic of Korea (Asset-Freezing) Regulations 2011; the Export Control (Russia, Crimea and Sevastopol Sanctions) Order 2014.

${ }^{113}$ The Child Minding and Day Care (Disqualification) (Wales) Regulations 2010; the Protection of Vulnerable Groups (Scotland) Act 2007 (Consequential Provisions) Order 2010; the Sea Fishing (EU Recording and Reporting Requirements) (Scotland) Order 2010; the Sea Fishing (Restriction on Days at Sea) (Scotland) Order 2010; the Water Resources (Control of Pollution) (Silage, Slurry and Agricultural Fuel Oil) (Wales) Regulations 2010; the Sulphur Content of Liquid Fuels (Scotland) Regulations 2014; the Environmental Protection (Duty of Care) (Scotland) Regulations 2014; and the Childcare (Childminder Agencies) (Cancellation etc.) Regulations 2014.

${ }^{114}$ See Explanatory Memorandum to the Protection of Vulnerable Groups (Scotland) Act 2007 (Consequential Provisions) Order 2010 at para 8.1.

${ }^{115}$ See Explanatory Memorandum to the Childcare (Childminder Agencies) (Cancellation etc.) Regulations 2014 at para 8.8 .

${ }^{116}$ Executive Note, The Sea Fishing (Restriction on Days at Sea) (Scotland) Order 2010 at para 4.

${ }^{117}$ Policy Note, The Plant Health (Forestry) (Phytophthora Ramorum Management Zone) (Scotland) Order 2014 at para 12.
} 
This is the accepted typescript of an paper accepted (in 2017) for publication in Legal Studies.

Legal Studies is available online at https://www.cambridge.org/core/journals/legal-studies

This copy was deposited in Enlighten before the final version of the article was published; it will appear in due course. This copy may be used only for private research and study and not distributed further.

As the JCSI has observed, ${ }^{118}$ the fact that a consultation took place does not tell the whole story. As noted earlier, ${ }^{119}$ the consultation might not reach those affected, consultees might not have the time or skills to respond and even if they do, this does not guarantee that any concerns will be given serious consideration. Some of the consultations in our sample were clearly extensive and led to changes to the draft regulations. One example is the Timeshare, Holiday Products, Resale and Exchange Contracts Regulations 2010, which created 14 offences, all subject to a maximum penalty of an unlimited fine. ${ }^{120} \mathrm{~A}$ lengthy consultation document containing a draft of the proposed regulations was sent to individual companies and to trader and consumer groups who were felt by the government to have a particular interest in the legislation. It was also placed on the Department for Business, Innovation and Skills website and notices were put in the national and trade press. ${ }^{121} \mathrm{~A}$ deadline of 12 weeks was set for responses ${ }^{122}$ and 23 responses were received. ${ }^{123}$ As a result, some changes were made to the draft Regulations, ${ }^{124}$ including the abandonment of some of the proposed criminal offences. ${ }^{125}$

Not all of the SIs in our sample were subject to such an extensive consultation. Low response rates appeared to be a problem - the consultation over the Seal Products Regulations 2010, for example, attracted only six responses. ${ }^{126}$ The consultation on the Products Containing Meat etc. Regulations

\footnotetext{
${ }^{118}$ The JSCI's concerns over the quality of consultation over secondary legislation are discussed in the text accompanying nn 183-192 below.

${ }^{119}$ See the text accompanying nn 94-95 above.

${ }^{120}$ Timeshare, Holiday Products, Resale and Exchange Contracts Regulations 2010, s 27.

${ }^{121}$ Department for Business Innovation and Skills, Implementation of EU Directive 2008/122/EC on Timeshare, Long-Term Holiday Products, Resale and Exchange Contracts: Government Response to Consultation and Final Impact Assessment (2010) at para 2.

122 Department for Business Innovation and Skills, Consultation on Implementation of EU Directive 2008/122/EC on Timeshare, Long-Term Holiday Products, Resale and Exchange Contracts (2010) at 7.

${ }^{123}$ Government Response, above n 121, at para 9.

$124 \mathrm{lbid}$, at paras 39, 101, 107.

$125 \mathrm{Ibid}$, at paras 404-432.

${ }^{126}$ Explanatory Memorandum to the Seal Products Regulations 2010 at para 8. The EM does not state whether these responses came from individuals or from representative bodies - if the latter, then the figure is perhaps of less concern.
} 
This is the accepted typescript of an paper accepted (in 2017) for publication in Legal Studies.

Legal Studies is available online at https://www.cambridge.org/core/journals/legal-studies

This copy was deposited in Enlighten before the final version of the article was published; it will appear in due course. This copy may be used only for private research and study and not distributed further.

(Northern Ireland) 2014 attracted none at all. ${ }^{127}$ This may, of course, indicate that those affected by the instrument in question were happy with the proposed legislation, ${ }^{128}$ but it may equally mean that the consultation did not reach its target audience or that consultees were unable to respond. The Government's account of the consultation process was also very sparse at times, meaning that it was difficult to assess the degree of support for particular proposals or whether any negative responses had been considered and responded to. ${ }^{129}$

(v) What does all this tell us about democratic legitimacy?

In assessing the democratic legitimacy of the criminal offences in our sample, it should perhaps be said that legitimacy 'is not an all or nothing affair', ${ }^{130}$ but rather a matter of degree. ${ }^{131}$ With this in mind, the 21 SIs that were made under ARP are the least problematic in legitimacy terms, as they were subject to a parliamentary vote. ${ }^{132}$ Those made under NRP are more problematic. There was some parliamentary control in that for at least some of them Parliament set out maximum penalties for the offences concerned (although, as discussed above, this did not always happen and even where it did the maximum penalty concerned was still a substantial term of imprisonment). A more productive route for finding democratic legitimacy here may, however, be through participatory legitimacy. Almost all of the instruments made under NRP did involve some degree of consultation with affected interests. Questions remain, however, over the degree of legitimacy this bestowed, as

\footnotetext{
${ }^{127}$ Explanatory Memorandum to the Products Containing Meat etc. Regulations (Northern Ireland) 2014, at para 8.1.

${ }^{128}$ The consultation accompanying the Brucellosis (Scotland) Amendment Order 2014 attracted 'very limited feedback', which the Scottish Government took 'to signify that the consensus is acceptance of the proposal' (Policy Note, The Brucellosis (Scotland) Amendment Order 2014, at para 7).

129 It is common for the documentation accompanying the instrument to state simply that there was 'broad support' for the measures in question. See e.g. Policy Note, The Sea Fish (Prohibited Methods of Fishing) (Firth of Clyde) Order 2014 at para 5.

${ }^{130}$ Beetham and Lord, above $\mathrm{n} 87$, at 9.

${ }^{131}$ Sadurski, above $n 85$, at 390 .

${ }^{132}$ Issues surrounding scrutiny and the quality of the resulting legislation, discussed in the next section, remain.
} 
This is the accepted typescript of an paper accepted (in 2017) for publication in Legal Studies.

Legal Studies is available online at https://www.cambridge.org/core/journals/legal-studies

This copy was deposited in Enlighten before the final version of the article was published; it will appear in due course. This copy may be used only for private research and study and not distributed further.

the mere fact that a consultation took place does not necessarily mean that there was an

opportunity for genuine participation by those affected..$^{133}$

\section{THE ISSUE OF SCRUTINY}

Setting aside the question of democratic legitimacy, a further issue is whether statutory instruments containing criminal offences receive adequate scrutiny, especially when made by NRP. The two issues are not unrelated - the process of scrutiny is one that might be undertaken either by MPs, as democratic representatives, or by affected interest groups, via the process of consultation. Legislative scrutiny is an important part of the law making process in any context but where the legislation in question is creating criminal offences, it is of heightened significance. Criminal liability is 'the strongest formal censure that society can inflict'. ${ }^{134}$ As we have noted, ${ }^{135}$ quite aside from any deprivation of liberty (or other penalty) that may result, the collateral impact that a criminal conviction can have on the life of an individual or the reputation of a corporation can be farreaching. This is one reason why criminal liability should be imposed only where the law conforms to certain principles. In the present context, we focus on two principles in particular. ${ }^{136}$ The first is the principle of accessibility and fair notice, which dictates that it is clear in advance to those targeted by a provision exactly what conduct is criminal. ${ }^{137}$ This is especially important, given that the defence of ignorance of the law is so restrictive as to be almost non-existent. ${ }^{138}$ The second is the principle of

\footnotetext{
133 Page, above n 33, at 154.

${ }^{134}$ A Ashworth and J Horder Principles of Criminal Law (Oxford: Oxford University Press, 7th edn, 2013) at 1.

135 See the text accompanying nn 26-29 above.

${ }^{136}$ We do not suggest that these are the only relevant principles in this context - they are simply two concerns that are particularly pertinent in our sample of offences.

${ }^{137}$ A Ashworth 'Ignorance of the criminal law, and duties to avoid it' (2011) 74 MLR 1 at 4. As Ashworth explains (at 20-23), the State's obligation to make the criminal law accessible to citizens may require the production of simplified versions of legislative texts and the implementation of a communication strategy to ensure that those subject to the law can be expected to be aware of it. Space precludes a further discussion of these points here, but government guidance is clearly an important component of the state meeting its obligations in respect of accessibility and fair notice.

${ }^{138}$ On the particular problem posed by secondary legislation in this context, see the comments of Toulson LJ in Chambers [2008] EWCA Crim 2467 at [64] (discussed in Chalmers and Leverick, above n 7, at 559-560). On the
} 
This is the accepted typescript of an paper accepted (in 2017) for publication in Legal Studies.

Legal Studies is available online at https://www.cambridge.org/core/journals/legal-studies

This copy was deposited in Enlighten before the final version of the article was published; it will appear in due course. This copy may be used only for private research and study and not distributed further.

proportionality of sentence - the requirement that the penalty on conviction should be

proportionate to the seriousness of the breach concerned. ${ }^{139}$

In terms of these two principles, there were many instruments in our sample that performed well. It is certainly not the case that all SIs that create criminal offences are poorly drafted or contain disproportionate maximum penalties. There were, however, a number that left a lot to be desired in one or both of these respects. One example is the Water Environment (Controlled Activities) (Scotland) Regulations 2011 (the Water Regulations), created under section 20(1) of the Water Environment and Water Services (Scotland) Act 2003 (the Water Act). These Regulations create 130 criminal offences all subject to a maximum penalty of five years' imprisonment (or an unlimited fine). ${ }^{140}$ The Water Regulations perform well in terms of accessibility. For the most part, they explain in great detail exactly what must be done if criminal liability is to be avoided. ${ }^{141}$ They perform less well in terms of proportionality. Section 44(2) provides that a person convicted on indictment of any of the 130 offences contained in the Regulations is liable to a maximum penalty of five years' imprisonment. ${ }^{142}$ Some of the offences are clearly extremely serious and a maximum penalty of this magnitude is not inappropriate. So, for example, one of the prohibited activities is the discharge of water from a surface water drainage system that contains trade effluent or sewage or that otherwise results in the pollution of the water environment. ${ }^{143}$ In other instances, however, it is less clear that proportionate penalties are being applied. The Regulations also prohibit, for example, the

defence of ignorance of law, see Ormerod and Laird, above n 3, at 380-382; J Chalmers and F Leverick Criminal Defences and Pleas in Bar of Trial (Edinburgh: W. Green/SULI, 2006) chapter 13.

${ }^{139}$ Ashworth and Horder, above n 134, at 19.

${ }^{140}$ Unlike some of the instruments in our sample, they are, at the time of writing, still in force.

${ }^{141}$ See especially Sch 3 which sets out extremely detailed technical rules governing water related activity.

${ }^{142}$ As discussed earlier, the Act provides that criminal offences could be made in secondary legislation with a maximum penalty of five years' imprisonment. This was used as a blanket penalty for all the criminal offences created here.

${ }^{143}$ Sch 3 s 10. 
This is the accepted typescript of an paper accepted (in 2017) for publication in Legal Studies.

Legal Studies is available online at https://www.cambridge.org/core/journals/legal-studies

This copy was deposited in Enlighten before the final version of the article was published; it will appear in due course. This copy may be used only for private research and study and not distributed further.

operation of a weir that impedes the free passage of salmon or sea trout ${ }^{144}$ and the placing of a

boulder in a river that has a length, breadth or height greater than $10 \%$ of the channel width. ${ }^{145}$ It is not immediately apparent that these offences are of the same magnitude as the direct discharge of sewage into the water environment. The Water Regulations also contain a number of offences of failure to provide information to officials, all of which are strict liability, ${ }^{146}$ and all of which are also potentially subject to the five year maximum penalty. Bear in mind here that the Law Commission, in Criminal Liability in Regulatory Contexts, recommended that a failure to provide information or other assistance should not be a criminal offence at all unless it was intentional or reckless. ${ }^{147}$ The approach taken in the Water Regulations is despite their being made under ARP and subject to consultation whilst in draft. ${ }^{148}$

Another example is the Materials and Articles in Contact with Food (England) Regulations 2010 (the Contact with Food Regulations), which created 26 offences using the power contained in the Food Safety Act $1990 .{ }^{149}$ The Regulations were made under NRP but were consulted on while in draft. ${ }^{150}$ In terms of the accessibility of the provision, the Regulations are far from ideal. The offence creating provisions are contained in a number of different sections of the legislation. Section 13 deems breaches of the duties set out in sections 8,10 and 11 to be a criminal offence. Sections 8 is relatively straightforward. ${ }^{151}$ Section 10 , however, provides that 'no person may manufacture any regenerated cellulose film intended to come into contact with food using any substance or group of substances other than the substances named or described in Annex II'. Section 10(2) states that

\footnotetext{
144 Sch 3 s 1.

145 Sch 3 s 14.

${ }^{146}$ Which is not to say that a mens rea requirement would not be read in by the courts.

${ }^{147}$ Law Commission, above $\mathrm{n} 1$, at para 4.81.

${ }^{148}$ As required under Sch 2 of the Water Act.

${ }^{149}$ Under ss $16(2)$ and $17(1)$ and (2).

${ }^{150}$ See the Explanatory Memorandum to the Materials and Articles in Contact with Food (England) Regulations 2010 at para 8.3.

${ }^{151}$ And is highly specific in terms of the behaviour it prohibits: see e.g. $s$ 8(1).
} 
This is the accepted typescript of an paper accepted (in 2017) for publication in Legal Studies.

Legal Studies is available online at https://www.cambridge.org/core/journals/legal-studies

This copy was deposited in Enlighten before the final version of the article was published; it will appear in due course. This copy may be used only for private research and study and not distributed further.

'Annex II' is a reference to 'Annex II to Directive 2007/42/EC', thus requiring the reader to cross-refer to a European Directive. Section 10(4) prohibits the manufacture of any coating to film using any substance other than one listed in Annex II, III or IV to another Directive (this time Directive 2002/72/EC) except where such manufacture complies with the 'requirements, restrictions and specifications contained in those Annexes and in the 2009 Regulations'. The reader then has to move to the interpretation section of the Contact with Food Regulations to discover that 'the 2009 Regulations' means the Plastic Materials and Articles in Contact with Food (England) Regulations 2009. Section 11 also contains provisions that cross-refer to Directive 2002/72/EC and the 2009 Regulations.

Sections 4,5 and 6 contain entirely separate offence provisions. Section 4 provides that breach of certain specified provisions of another EU Regulation (Regulation 1935/2004) is an offence. Regulation 1935/2004 spans 13 pages of small font type and itself cross-refers to two further European Directives (Directive 89/107/EEC and Directive 2000/13/EC). Section 5 provides that breach of another EU Regulation (Regulation 2023/2006) is an offence, as does section 6 (Regulation 450/2009). Regulation 450/2009 makes a number of references to 'the Community list' which, it is stated in the preamble, is 'a list of authorised substances that may be used in active and intelligent components' but there is no indication of where this list might be found.

In terms of the applicable penalties, the Contact with Food Regulations look, on the face of it, like a more considered set of provisions, in that the drafters have separated out different offences as meriting maximum penalties of different magnitude. So section $13(1)(b)$ provides that intentionally obstructing or failing to provide assistance or information to a person acting in the execution of the Regulations is an offence and section 13(2)(b) demarcates this as a less serious offence than breaches of the substantive duties, with a maximum penalty of three months' imprisonment 
This is the accepted typescript of an paper accepted (in 2017) for publication in Legal Studies.

Legal Studies is available online at https://www.cambridge.org/core/journals/legal-studies

This copy was deposited in Enlighten before the final version of the article was published; it will appear in due course. This copy may be used only for private research and study and not distributed further.

(compared to two years). No such distinction is made, however, in relation to the EU legislation referred to in the Contact with Food Regulations, breach of which is also an offence, despite the fact that it contains duties of assistance and information provision similar to those in section $13(1)$ (b). So, for example, Article 12 of Regulation 450/2009 provides that 'appropriate documentation to demonstrate that the active and intelligent materials and articles and the components intended for the manufacturing of those materials and articles comply with the requirements of this Regulation shall be made available by the business operator to the national competent authorities on request'. Under section 6 of the 2010 Regulations, breach of this article is an offence subject to a maximum penalty of two years' imprisonment. Similar information provision duties are contained in other parts of Regulation $450 / 2009^{152}$ and in the other EU legislation ${ }^{153}$ to which the 2010 Regulations refer and these too attract a maximum penalty of two years' imprisonment.

A further example is the Animal By-Products (Enforcement) (England) Regulations 2011 (the ByProducts Regulations). These were made under powers contained in the Agriculture Act $1970^{154}$ and the European Communities Act 1972 and created 36 criminal offences. While they were made under NRP, they were the subject of a consultation while in draft. ${ }^{155}$ To discover precisely what activity is a criminal offence, it is necessary to start at section $17(1)$, which provides that 'a person who fails to comply with an animal by-product requirement commits an offence'. Section $17(2)$ states that 'animal by-product requirement' means 'any requirement in Column 2 of Schedule 1 to the ByProducts Regulations as read with the provisions in Column 3 to that Schedule'. Columns 2 and 3 in Schedule 1 do not themselves shed any light on the nature of the prohibited conduct. Instead they

\footnotetext{
152 See e.g. Article 12(1).

153 See e.g. Regulation 2023/2006 articles 6(2), 7(1) and 7(2); Regulation 1935/2004 articles 11(5), 16(1) and $17(2)$.

154 Section 84.

155 Explanatory Memorandum to the Animal By-Products (Enforcement) (England) Regulations 2011 at para
} 8.1. 
This is the accepted typescript of an paper accepted (in 2017) for publication in Legal Studies.

Legal Studies is available online at https://www.cambridge.org/core/journals/legal-studies

This copy was deposited in Enlighten before the final version of the article was published; it will appear in due course. This copy may be used only for private research and study and not distributed further.

list 23 articles of 'the EU Control Regulation' each of which should be read with various provisions of 'the EU Implementing Regulation'. It is then necessary to turn to the interpretation section of the ByProducts Regulations (section 2) to discover that the EU Control Regulation means Regulation EC No.1069/2009 and that the EU Implementing Regulation means Commission Regulation EU No.142/2011. To discover what conduct is actually prohibited, it is necessary to seek out both items of European legislation. The EU Control Regulation contains 33 pages of small font type and some of the offence creating Articles themselves cross-refer to other European legislation. ${ }^{156}$ In terms of proportionality, the By-Products Regulations are also problematic. Section 20 provides for a blanket maximum penalty upon conviction on indictment of two years' imprisonment. This applies to substantive breaches of the Regulations just as it does to offences of failing to provide information or assistance. ${ }^{157}$

It should be stressed again that not all of the SIs we examined performed poorly in terms of clarity and proportionality in sentencing. ${ }^{158}$ Those discussed above, however, were not the only instruments that were problematic in these terms. They were selected for discussion because they all carry heavy maximum penalties, but there were numerous examples of instruments with less severe penalties that were equally problematic. ${ }^{159}$ These problems existed despite the presence of the SI Committees and despite the instruments concerned being the subject of consultation exercises.

\footnotetext{
${ }^{156}$ See e.g. Article 6, which refers to 'Annex 1 to Directive 92/119/EEC'; Article 24, which refers to 'Regulation EC No.183/2005'.

${ }^{157}$ There are specific offences of failing to provide information etc. in $\mathrm{s} 18$ but some of the EU legislation also contains duties to provide information, breach of which is an offence with a maximum penalty of two years' imprisonment under the By-Products Regulations.

${ }^{158}$ Nor do we mean to suggest that primary legislation, which falls outside the scope of this paper, avoids these difficulties, as we note below.

${ }^{159}$ See e.g. the Merchant Shipping (International Safety Management (ISM) Code) Regulations 2014 (where discovering the precise conduct that is criminalised involves a labyrinthine trawl through a lengthy EU Regulation and a search for the ISM Code adopted by the International Maritime Organisation in 1993) and the Salmon Netting Regulations (Northern Ireland) 2014 (which prohibits the use of various methods to fish for salmon, but nowhere in the Regulations does it mention that using these methods is a criminal offence).
} 
This is the accepted typescript of an paper accepted (in 2017) for publication in Legal Studies.

Legal Studies is available online at https://www.cambridge.org/core/journals/legal-studies

This copy was deposited in Enlighten before the final version of the article was published; it will appear in due course. This copy may be used only for private research and study and not distributed further.

\section{OPTIONS FOR CHANGE}

Thus far, we have demonstrated that substantial numbers of criminal offences, often with heavy maximum penalties, are created in the UK in delegated legislation. This is potentially problematic both in terms of the democratic legitimacy of the criminal law thus created and in terms of its clarity and proportionality. With respect to the former, such legitimacy might be bestowed by parliamentary vote (as in the case under ARP procedure) or by direct participation in the legislative process via consultation. The majority of the SIs we looked at were either made under ARP or were subject to a consultation process (although there were a small minority of instruments where neither of these was the case). That said, it was not always obvious that the consultation process was particularly thorough or well documentedand if this is to be the basis upon which democratic legitimacy is bestowed, it leaves something to be desired. With respect to the content of the legislation, while many of the criminal offences defined in the SIs in our sample were very well drafted, there were a number of examples where criminal offences were confusingly defined, where apparently disproportionate maximum penalties were attached to some offences, or even where it was difficult to establish without very careful reading of the provisions exactly what conduct had been criminalised.

If these issues are to be addressed, there are a number of different ways forward, which could be deployed as alternatives or in combination. Each is discussed in turn.

\section{(a) Limiting delegation}

One possibility is to prevent the power to create criminal offences being delegated at all and require all criminal offences to be contained in primary legislation, and voted on by Parliament, as was 
This is the accepted typescript of an paper accepted (in 2017) for publication in Legal Studies.

Legal Studies is available online at https://www.cambridge.org/core/journals/legal-studies

This copy was deposited in Enlighten before the final version of the article was published; it will appear in due course. This copy may be used only for private research and study and not distributed further.

proposed by the Law Commission in Criminal Offences in Regulatory Contexts. ${ }^{160}$ This would address any concerns that direct consultation is an inadequate method of securing democratic legitimacy, either in theory or in practice. It would also improve the degree of scrutiny that the legislation receives, with the result that problems with clarity or proportionality of penalty are more likely to be identified prior to the legislation coming into force. That is not to say, of course, that primary legislation is always of high quality ${ }^{161}$ Although difficulties of clarity are often exacerbated by the relatively technical matter of secondary legislation, there are plenty of examples of primary legislation containing criminal law provisions that leave much to be desired in terms of the quality of their drafting. ${ }^{162}$ The scrutiny that primary legislation receives compared to delegated legislation ${ }^{163}$ means, however, that problematic issues are far more likely to be identified and addressed in the former than the latter.

The Law Commission's proposal attracted some support in consultation responses ${ }^{164}$ but it was also pointed out that this would be wholly impractical as there would be insufficient parliamentary time to pass all the legislation that creates criminal offences. ${ }^{165}$ The Law Commission's recommendation does need to be considered in the context of its other proposals, including the increased use of civil penalties to replace relatively minor criminal offences, ${ }^{166}$ so the problem of parliamentary time

\footnotetext{
${ }^{160}$ Law Commission, above n 1, at paras 1.49, 3.157.

${ }^{161}$ We have previously criticised the clarity of primary legislation in this context: see Chalmers and Leverick, above $\mathrm{n}$ 7, at 549-550.

162 See e.g. $\mathrm{s} 1$ of the Offensive Behaviour at Football and Threatening Communications (Scotland) Act 2012, discussed in J Chalmers and F Leverick The Criminal Law of Scotland, Volume II (Edinburgh: W. Green/SULI, 4th edn, 2016) at paras 49.16-49.17; s 46 of the Serious Crime Act 2007, discussed in Ormerod and Laird, above $n$ 3 , at 542-547.

${ }^{163}$ See section 3 above.

164 Law Commission Criminal Liability in Regulatory Contexts: Responses (2010) at e.g. paras 1.784 (Criminal Sub-Committee of the Council of HM Circuit Judges); 1.794 (The Law Society); and 1.804 (the Magistrates Association).

${ }^{165}$ See e.g. the responses from the Food Standards Agency (para 1.785) and the Criminal Bar Association and Bar Council (para 1.825).

${ }^{166}$ See Law Commission, above n 1, at para 4.7.
} 
This is the accepted typescript of an paper accepted (in 2017) for publication in Legal Studies. Legal Studies is available online at https://www.cambridge.org/core/journals/legal-studies

This copy was deposited in Enlighten before the final version of the article was published; it will appear in due course. This copy may be used only for private research and study and not distributed further.

might not be insurmountable. Given the sheer number of offence creating SIs in our sample, ${ }^{167}$ however, it would require a radical - and not uncontroversial ${ }^{168}$ - shift to the use of civil penalties in place of criminal offences to even begin to be feasible.

A less radical option would be to stipulate that the power to create serious criminal offences cannot be delegated, leaving the possibility that relatively minor offences could still be created in secondary legislation. ${ }^{169}$ This is precisely the system that exists in France, where there is a constitutional principle that the power to create serious offences cannot be delegated. ${ }^{170} \mathrm{~A}$ similar principle exists in Germany. ${ }^{171}$ One difficulty in the UK context would be how to determine what is a serious offence. In France this is straightforward, given the three tier classification of offences into crimes, délits and contraventions. ${ }^{172}$ It is only contraventions (which cannot be punished by imprisonment ${ }^{173}$ ) that can be made in secondary legislation - crimes and délits must be created in primary legislation. ${ }^{174}$

In none of the UK jurisdictions does a formal system for classifying the seriousness of offences exist, but a line could be drawn on the basis of the magnitude of the penalty concerned. So it would be possible, for example, to mandate that all imprisonable offences be created in primary legislation or that all offences with a penalty of more than one or two years' imprisonment must be made in

\footnotetext{
${ }^{167}$ There were 98 in the 2014 sample (excluding instruments of local applications and Privy Council Orders in Council). To put this in context, 72 Acts of Parliament were passed in 2014.

${ }^{168}$ For critical discussion, see e.g. RM White “"Civil penalties”: oxymoron, chimera or stealth sanction?' (2010) 126 LQR 593; K Yeung 'Better regulation, administrative sanctions and constitutional values' (2013) 33 LS 312. 169 It should be said that in effect this is not that different from the Law Commission's proposal, given that for the Commission the criminal law should be reserved only for serious breaches.

${ }^{170}$ Article 34 of the French Constitution provides that 'La loi fixe les règles concernant ... la détermination des crimes et délits ainsi que les peines qui leur sont applicables'. The English translation offered by the French National Assembly website translates this as: 'Statutes shall determine ... the rules concerning the determination of serious crimes and other major offences and the penalties they carry.'

${ }^{171}$ See T Weigend 'The legal and practical problems posed by the difference between criminal law and administrative penal law' (1988) 59 Revue International de Droit Pénal 67 at 69-70.

172 French Penal Code, Article 111-1.

${ }^{173}$ French Penal Code, Article 131-12.

${ }^{174}$ The French version of Article 34 Constitution specifically refers to 'crimes et délits' although this is lost in the English translation offered by the French National Assembly.
} 
This is the accepted typescript of an paper accepted (in 2017) for publication in Legal Studies.

Legal Studies is available online at https://www.cambridge.org/core/journals/legal-studies

This copy was deposited in Enlighten before the final version of the article was published; it will appear in due course. This copy may be used only for private research and study and not distributed further.

primary legislation. As we saw earlier, some enabling legislation already places limits of this nature.

Such an approach is a pragmatic one: it does not involve a claim that length of potential

imprisonment is the only factor relevant to legitimacy, and it might in some instances be inappropriate to use subordinate legislation where (for example) conviction was likely to be unusually stigmatic or have serious effects on an individual's life separate from stigma or imprisonment, such as by disqualifying a person from particular activities. Any such issues would have to be considered on a case by case basis (and could be taken account of by the relevant Parliamentary committees), but a rule based on a maximum term of imprisonment provides a bright line rule that can easily be applied in practice. The difficulty would be in determining where to draw that line. If it is drawn too high (say at two years' imprisonment), it will have little effect (or may simply result in Ministers creating offences with penalties just below the maximum). If it is drawn too low, it may mean that Parliament cannot cope with all the legislation that would now have to proceed through the primary legislation making process.

If secondary legislation is retained as a way of creating criminal offences - either for all offences or only for relatively minor ones - another option could be to mandate that ARP must be always used. ${ }^{175}$ As we saw earlier, some of the enabling Acts in our sample did just this, providing that ARP must be used to make any regulations that created criminal offences (or increased the penalties for existing offences). ${ }^{176}$ Secondary legislation does have advantages - it can be passed rapidly when there is a need to react quickly to events or where the law needs to be regularly changed or updated $^{177}$ - and the use of ARP would mean that the resulting criminal offences are voted on by

\footnotetext{
${ }^{175}$ A suggestion made by the Joint Committee on Delegated Legislation, Second Report (HL204/HC468, 197273) at para 46.

${ }^{176}$ See e.g. the Sunbeds Regulation Act 2010 s 11(2) and (3) (under which the Sunbeds Regulation Act 2010 (Wales) Regulations 2011 were made).

177 J Burrows 'Legislation: primary, secondary and tertiary' (2011) 42 Victoria University of Wellington LR 65 at 65.
} 
This is the accepted typescript of an paper accepted (in 2017) for publication in Legal Studies.

Legal Studies is available online at https://www.cambridge.org/core/journals/legal-studies

This copy was deposited in Enlighten before the final version of the article was published; it will appear in due course. This copy may be used only for private research and study and not distributed further.

Parliament. ARP does, however, leave much to be desired in terms of the opportunity for scrutiny and - if necessary - amendment during the law making process and it is clear from our sample that its use did not prevent poor quality legislation from becoming law. ${ }^{178}$

\section{(b) Participation through consultation}

A final way forward - which might be deployed in combination with other changes or as a standalone option - is to rely on participation as a route to democratic legitimacy and scrutiny of legislative content. Where a criminal offence is created in an instrument made by NRP, consultation is essential for democratic legitimacy, but there is a good argument for requiring this for all legislation that creates criminal offences, in order that the Parliamentary scrutiny inherent in ARP and primary legislation can be effective and properly informed. What is important here is not simply that a consultation exercise takes place (as it did for almost all of the SIs in our sample), but that it is of sufficient quality in terms of, for example, its reach and the timeframe for responses, and that responses received (especially where they do not support the proposals) are given adequate consideration. It is worth noting again that consultation did not prevent the accessibility and proportionality problems identified earlier.

There are two main checks that already exist on the quality of consultation. One is the UK Government's Consultation Principles, ${ }^{179}$ which apply to all Government consultations, including those relating to SIs. Under these guidelines, consultations should, inter alia, be targeted at appropriate groups; they should last for a proportionate amount of time, taking into account the nature and impact of the proposal; responses should be published within twelve weeks of the close

\footnotetext{
${ }^{178}$ See the discussion of the Water Environment (Controlled Activities) (Scotland) Regulations 2011 above.

${ }^{179}$ Cabinet Office Consultation Principles: Guidance (2016), available at https://www.gov.uk/government/publications/consultation-principles-guidance. In the Scottish context, see Scottish Government Consultation Good Practice Guidance (2008).
} 
This is the accepted typescript of an paper accepted (in 2017) for publication in Legal Studies. Legal Studies is available online at https://www.cambridge.org/core/journals/legal-studies This copy was deposited in Enlighten before the final version of the article was published; it will appear in due course. This copy may be used only for private research and study and not distributed further.

of the consultation (or an explanation should be provided as to why this was not possible); and information should be provided about how many responses were received, the nature of these responses and how these have informed the policy (or here the SI) in question. Aside from the twelve week publication deadline, however, the guidelines lack any real specificity and are only guidelines. There is no sanction if they are not complied with.

The second check exists via the Committee system. As we have already noted, ${ }^{180}$ as a direct result of concerns it had repeatedly expressed about the quality of consultations accompanying SIs, the JCSI was, from parliamentary session 2014-15, given a new term of reference to draw attention to instruments that had been subject to inadequate consultation. In the latest version of its guidance, the JCSI specifically states that it: ${ }^{181}$

considers that proper consultation is a crucial part of the process of getting an instrument right before it is laid. As the House cannot amend secondary legislation, it is important that each instrument should have been exposed to those who will be affected by its provisions and its suitability reviewed in the light of their reactions before it is laid before Parliament.

The Explanatory Memorandum accompanying a statutory instrument, the JCSI continues, should:182

set out who was consulted, over what period and how many people responded. There should be some analysis of the key points raised in responses and a short justification of why the department did or did not make changes to its policy in the light of the opinions expressed.

\footnotetext{
180 See text accompanying $\mathrm{n} 47$ above.

${ }^{181}$ Guidance for Departments, above n 47, at 10.

182 Ibid.
} 
This is the accepted typescript of an paper accepted (in 2017) for publication in Legal Studies. Legal Studies is available online at https://www.cambridge.org/core/journals/legal-studies This copy was deposited in Enlighten before the final version of the article was published; it will appear in due course. This copy may be used only for private research and study and not distributed further.

This does not mean, though, that any instrument that has not been the subject of a proper consultation process will be annulled. As noted earlier, the JCSI (and its Scottish equivalent) can only draw attention to an instrument. It is then reliant on a successful motion to annul (or on the Government voluntarily withdrawing the SI), something that happens very rarely. The fact that the JCSI has signalled its intention to scrutinise the consultation process might still mean that government departments are more likely to ensure that adequate consultation with affected interests does take place. There is little evidence, however, that the existence of the new reporting ground has prevented poor quality consultation. In a report written at the end of the first parliamentary session after the new reporting ground came into operation, ${ }^{183}$ the JCSI noted that there were still 'too many examples where an important policy development has been preceded by a poorly conceived consultation exercise'. ${ }^{184}$ It had, as of January 2015 , reported five instruments on the basis of inadequate consultation ${ }^{185}$ and had also noted problems in the consultation process in relation to instruments reported under other grounds. ${ }^{186}$ The problems noted included very short timeframes (often only a matter of a few weeks and on a number of occasions - including an instrument that related to schools - over the summer holiday period) ${ }_{1}^{187}$ confusing presentation of proposals, ${ }^{188}$ not consulting widely enough, ${ }^{189}$ failing to mention opposition to proposals in the Explanatory Memorandum to the $\mathrm{SI}^{190}$ proceeding with an instrument despite significant

\footnotetext{
183 House of Lords Secondary Legislation Scrutiny Committee 22nd Report of Session 2014-15, Inquiry into Government Consultation Practice (London: House of Lords, HL Paper 98, 2015).

${ }^{184}$ Ibid, at para 52.

$185 \mathrm{Ibid}$, at para 12.

$186 \mathrm{Ibid}$, at para 22.

$187 \mathrm{Ibid}$, at paras 16, 18, 20, 27 and 28.

$188 \mathrm{lbid}$, at para 16.

189 Ibid, at para 24.

190 Ibid, at para 10.
} 
This is the accepted typescript of an paper accepted (in 2017) for publication in Legal Studies.

Legal Studies is available online at https://www.cambridge.org/core/journals/legal-studies

This copy was deposited in Enlighten before the final version of the article was published; it will appear in due course. This copy may be used only for private research and study and not distributed further.

opposition, ${ }^{191}$ and in one case holding no consultation at all on the basis that there was no time to do so. ${ }^{192}$

It is difficulties such as these that have led some to argue that the UK jurisdictions should adopt something akin to the Administrative Procedure Act 1946 (APA) that regulates the making of secondary legislation in the US. ${ }^{193}$ In the US delegated legislation is most commonly made not by government departments but by independent regulatory bodies, ${ }^{194}$ but in doing so they must comply with, inter alia, the requirement for consultation in section 4 of the APA. ${ }^{195}$ This requires an agency to give notice of the terms of any proposed new rules, ${ }^{196}$ to afford interested parties an opportunity to participate in the rule making by making written or oral submissions and to consider all relevant submissions received, ${ }^{197}$ and to allow at least 30 days between publication of a rule and its effective date. ${ }^{198}$ Perhaps more significantly, the courts have added substance to the rules as set out in the APA. Agencies must fairly present the substance of the rules, disclose the methodology and supporting studies behind them, disclose any additional factual information that comes to light during the rulemaking process and explain alternatives that were rejected. ${ }^{199}$ Failure to comply sets up the possibility of a successful judicial review of the resulting legislation if the consultation was not carried out in accordance with procedure. ${ }^{200}$ Regulating the consultation process in this way will not, of course, necessarily result in full participation by those potentially affected by offence creating

\footnotetext{
$191 \mathrm{lbid}$, at paras 25 and 26.

192 Ibid, at para 21

193 See e.g. Pünder, above $n$ 88, at 375-377.

194 See Asimow, above n 63, at 254-261; Pünder, above n 88, at 359-371.

195 Discussed in detail by Asimow, above $n$ 63, at 254-261; Pünder, above $n$ 88, at 359-360.

${ }^{196}$ Section 4(1)(a).

197 Section 4(2)(b).

198 Section 4(2)(c).

${ }^{199}$ Asimow, above $n$ 63, at 256.

200 Ibid.
} 
This is the accepted typescript of an paper accepted (in 2017) for publication in Legal Studies.

Legal Studies is available online at https://www.cambridge.org/core/journals/legal-studies

This copy was deposited in Enlighten before the final version of the article was published; it will appear in due course. This copy may be used only for private research and study and not distributed further.

regulations. ${ }^{201}$ It would, however, constitute an improvement on the present situation in the UK where the available evidence suggests that the quality of consultation is highly variable. ${ }^{202}$

\section{CONCLUSION}

In the preceding analysis, we have demonstrated that the creation of criminal offences is largely a matter of administrative action (in the form of delegated legislation) rather than a Parliamentary decision and that substantial numbers of criminal offences are being created in delegated legislation which carry heavy maximum penalties. This presents a challenge to the orthodox position in criminal law scholarship, which treats criminalisation as a solemn matter for the legislature, and where debate has focused primarily on the criteria that should be used to determine the content of the criminal law and on the principles - such as fair notice and proportionality of sentence - to which such offences should conform. This scholarship is immensely valuable, but the process by which criminal offences are created should also be given critical attention.

The extensive creation of criminal offences by delegated legislation raises an important question, which is how such criminalisation is to be regarded as democratically legitimate, if it is not voted on by Parliament. Such democratic legitimacy might be secured through the implementation of effective consultation processes, but we question whether this is sufficient in respect of offences which carry (sometimes lengthy) periods of imprisonment as a maximum penalty. While Parliament clearly cannot be constrained from delegating the power to create imprisonable offences if it so desires, it would be desirable, as a matter of practice, to apply a principle that serious criminal offences should only be created by primary legislation, with seriousness being defined by reference to the maximum sentence of imprisonment applicable on conviction. Exactly where the threshold

\footnotetext{
${ }^{201}$ See the discussion in Page (above $n$ 33, at 138-139), where he records civil servants describing their frustration at low response rates to even well managed consultations.

${ }^{202}$ Aside from the JCSI's report, see Page (above n 33, at 154).
} 
This is the accepted typescript of an paper accepted (in 2017) for publication in Legal Studies.

Legal Studies is available online at https://www.cambridge.org/core/journals/legal-studies

This copy was deposited in Enlighten before the final version of the article was published; it will appear in due course. This copy may be used only for private research and study and not distributed further.

should be drawn is a matter for further debate - but it is important that it is drawn at a level that is neither ineffective nor places too heavy a burden on parliamentary capacity.

For less serious offences, however, democratic legitimacy is still a concern. The stigma of a criminal conviction is potentially very serious, and the collateral consequences (for individuals and corporations) can be very severe, even where the direct penalty imposed is relatively minor. The importance of the consultation processes in legitimating secondary legislation that creates criminal offences must be sufficiently recognised and consultation - if it is to do the work of legitimating the criminal law - must be taken seriously and done properly. While recent developments in this area are promising, the problems identified in the JCSI's 2015 report indicate that there is still work to be done in ensuring that full and proper consultation is carried out in all cases where criminal offences are created by delegated legislation. One way forward could be to adopt in the UK jurisdictions something akin to the Administrative Procedure Act 1946 to regulate criminal law making in delegated legislation, by imposing a blanket legal requirement of consultation and by setting out procedural and reporting criteria which must be met in terms of, for example, the timeframe for responses and the regard that must be given to any opposition expressed.

Together, these measures - requiring parliamentary approval for the creation of serious criminal offences and mandating a proper consultation process for the remainder - would address the concerns we have articulated about the democratic legitimacy of creating criminal offences via delegated legislation. They may also have a positive effect on the quality of the delegated legislation concerned, by improving the degree of scrutiny it receives. That is not to say, of course, that all problems with the quality of criminal law would disappear. Parliamentary scrutiny does not necessarily result in perfect legislation - the best that can be said is that the higher degree of scrutiny primary legislation receives compared to delegated legislation reduces the risk of difficulties 
This is the accepted typescript of an paper accepted (in 2017) for publication in Legal Studies. Legal Studies is available online at https://www.cambridge.org/core/journals/legal-studies This copy was deposited in Enlighten before the final version of the article was published; it will appear in due course. This copy may be used only for private research and study and not distributed further.

occurring. There is also a limit to what consultation can achieve in this respect. Even the bestpublicised and lengthy of consultations may not succeed in attracting responses. Ensuring that affected parties are at least afforded the opportunity to participate in this way and that the results of such consultation are openly and fully recorded would nonetheless represent an improvement on the present position. 